\title{
Influence of ethnic origin (Asian $v$. Caucasian) and background diet on the bioavailability of dietary isoflavones
}

\author{
Sébastien Vergne ${ }^{1,2,3}$, Patrick Sauvant ${ }^{1,3}$, Valérie Lamothe ${ }^{1,3}$, Philippe Chantre ${ }^{2}$, Julien Asselineau ${ }^{4}$, \\ Paul Perez ${ }^{4}$, Marlène Durand ${ }^{5}$, Nicholas Moore ${ }^{6}$ and Catherine Bennetau-Pelissero ${ }^{1,3 *}$ \\ ${ }^{1}$ Université de Bordeaux, Talence Cedex F-33405, France \\ ${ }^{2}$ Arkopharma SA, Laboratoires Pharmaceutiques, Carros 06510, France \\ ${ }^{3}$ ENITA de Bordeaux, 1, cours du Général de Gaulle, CS 40201, Gradignan Cedex F-33175, France \\ ${ }^{4}$ Unité de Soutien Méthodologique à la Recherche clinique et épidémiologique, CHU de Bordeaux, ISPED, 33076 Bordeaux, \\ France \\ ${ }^{5}$ Centre d'Investigation Clinique (CIC), INSERM, CHU de Bordeaux, Bordeaux, France \\ ${ }^{6}$ Département de Pharmacologie, Université de Bordeaux, INSERM U657, Bordeaux, France
}

(Received 9 October 2008 - Revised 3 June 2009 - Accepted 8 June 2009 - First published online 22 July 2009)

Soya isoflavones: genistein and daidzein are increasingly consumed in Western countries. Their beneficial effects are discussed considering nutrition and health in Asia. The present study aimed to check whether chronic ingestions, ethnic origin and dietary context can influence soya phyto-oestrogen bioavailability. Two prospective trials were carried out to blindly assess the pharmacokinetics after acute and chronic intake of soya-based cheese (45.97 (SD1.57) mg isoflavones) taken once a day for $10 \mathrm{~d}$. Twelve healthy young Asians immersed for 2 months in France were randomised in a cross-over design to compare the influence of a Western $v$. Asian dietary context. The second trial partly nested in the first one, compared Asians under the Western diet to twelve healthy young male Caucasians under the same diet. All volunteers were non-equol producers. After an acute intake of soya in Western diet, Asians exhibited higher maximum concentration measured in plasma $\left(C_{\max }\right)$ and area under the plasma concentration-time curve (AUC) for genistein and daidzein than Caucasians $(P=0.005,0 \cdot 006,0 \cdot 032$ and $0 \cdot 008$, respectively). In Caucasians under Western diet, AUC and $C_{\max }$ values significantly increased after chronic intake. This was not the case for daidzein in Asians whatever the dietary context. For the first time, it is evidenced that on acute intake of soya cheese, Asians absorb soya phyto-oestrogens better than Caucasians, regardless of whether the background diet is Western or Asian. On chronic ingestions, AUC and $C_{\max }$ values were increased for daidzein and genistein in Caucasians but not in Asians. There are ethnical differences in isoflavone pharmacokinetic and bioavailability. This may influence health outcomes.

Asians: Caucasians: Soya isoflavones: Pharmacokinetics

Genistein and daidzein are phyto-oestrogens interacting with oestradiol receptors and highly concentrated in soybeans. The current interest in these isoflavones has resulted in a significant number of publications on their potential efficacy in improving welfare and health. However, much data on their consumption and their bioavailability are still lacking even though several reviews exist on their bioavailability ${ }^{(1-3)}$. Soya products are traditionally used in many Asian countries. In Japan, the mean total intake of isoflavones is estimated between 39 and $47.2 \mathrm{mg} / \mathrm{d}^{(4-6)}$. In China, the mean intake was evaluated at $17.7 \mathrm{mg} / \mathrm{d}^{(7)}$ or at $25.4 \mathrm{mg} / \mathrm{d}^{(8)}$. In Korea, the soya isoflavone intake was estimated at $20.9 \mathrm{mg} / \mathrm{d}^{(9)}$. In contrast, in Western countries, daily isoflavone intake was evaluated at $<2 \mathrm{mg}^{(10)}$. However, clinical studies were often performed on Westerners using high isoflavone intake from $10 \mathrm{mg}$ up to $240 \mathrm{mg} / \mathrm{d}^{(11-13)}$ with a current exposure between 60 and $100 \mathrm{mg}^{(1)}$. Isoflavone concentrations in the plasma of Asians under a traditional diet were found to be higher than those of non-Asians under their traditional diet ${ }^{(14)}$. However, to date, no study has assessed the influence of ethnic origin either on the bioavailability or on the pharmacokinetics of isoflavones. The ethnic origin was shown to influence the bioavailability of dietary components either via inter-ethnic genetic differences ${ }^{(15)}$ or gut flora interethnic differences ${ }^{(16)}$. Over the past 10 years, Westerners have been increasingly exposed to soya isoflavones through the consumption of soya food or isoflavone supplements ${ }^{(17)}$. Nevertheless, the knowledge of isoflavone pharmacokinetics especially on chronic ingestions is required to determine an appropriate intake of soya isoflavones, and allow health professionals to give appropriate advice. Recent reviews have dealt with several factors influencing the bioavailability of isoflavones ${ }^{(3,18)}$. The effect of chronic soya exposure is still controversial.

Abbreviations: $\mathrm{AUC}_{\infty}$, area under the time-concentration curve extrapolated to infinity; $\mathrm{AUC}_{24 \mathrm{~h}}$, area under the time-concentration curve calculated on a $24 \mathrm{~h}$ basis; BW, body weight; $C_{\max }$, maximum concentration measured in plasma; $T_{\max }$, time at which $C_{\max }$ is measured; $t_{1 / 2}$, half-life period.

* Corresponding author: Catherine Bennetau-Pelissero, fax +33 5573507 59, email c-bennetau@enitab.fr 
Several data showed metabolism adaptation and others did not ${ }^{(19-22)}$. Traditional Asian food is considered to be different from Western food ${ }^{(23)}$ and responsible for specific health characteristics. To our knowledge, no studies comparing the effects of either Asian or Western background diets on the pharmacokinetics of soya isoflavones have so far been conducted.

This clinical trial investigates for the first time whether: (i) ethnicity (Asian v. Caucasian); (ii) once only $v$. chronic soya exposure or (iii) background diet may influence isoflavone pharmacokinetics of the main soya isoflavones.

\section{Methods}

Twelve French Caucasian and twelve Chinese Asian healthy young male volunteers were recruited. Most of the Asians were visiting students and had been in France for 2 months when the experiment began. Subjects were interviewed in their native language on their usual dietary preferences. Asians were mainly on a traditional Asian diet served at the school restaurant with the agreement of dieticians. They could also have Asian or Western food from a takeaway restaurant collaborating with the study with the agreement of dieticians, and consumed in the subjects' private accommodation. Caucasians were invited to follow their usual Western dietary habits currently proposed at the French school restaurant and checked by dieticians. Volunteers were mainly non-smokers (nineteen out of twenty-four, four smokers among Caucasian volunteers). None of the smokers had more than ten cigarettes per day, and they were asked not to consume alcohol and to keep on with their usual physical activities. Cigarette consumption was maintained in order not to modify liver metabolism just before the study. All subjects were aged between 20 and 30 years old, with a BMI between 19.4 and $25.5 \mathrm{~kg} / \mathrm{m}^{2}$ (Table 1). The protocol was explained to subjects in their native language and they provided written informed consent. The previous medical history of the volunteers was checked as well as their current health status. A biological blood test was performed to check for digestive, liver or kidney disease. Exclusion criteria were any digestive, liver or kidney pathologies, excessive cigarette or drug consumption, and excessive alcohol, coffee or tea consumption. Secondarily, equol production became an exclusion criterion to homogenise the volunteer population. The subjects had to abstain from consuming any drugs, especially antibiotics, for at least $30 \mathrm{~d}$ before the beginning of the study and during it. Subjects were not authorised to consume

Table 1. Characteristics of the volunteers enrolled in the studies* $^{*}$

(Mean values and standard deviations)

\begin{tabular}{lccccc}
\hline & \multicolumn{2}{c}{$\begin{array}{c}\text { Caucasian } \\
\text { volunteers }(n 12)\end{array}$} & & \multicolumn{2}{c}{$\begin{array}{c}\text { Asian volunteers } \\
(n \text { 12) }\end{array}$} \\
\cline { 2 - 3 } \cline { 5 - 6 } & Mean & SD & & Mean & SD \\
\hline Age (years) & 23.6 & 3.6 & & 26.1 & 2.1 \\
Weight $(\mathrm{kg})$ & 74.0 & 7.6 & & 68.3 & 8.1 \\
Height $(\mathrm{m})$ & 1.81 & 0.06 & & 1.76 & 0.05 \\
BMl $\left(\mathrm{kg} / \mathrm{m}^{2}\right)$ & 22.7 & 1.7 & & 22.0 & 2.2 \\
\hline
\end{tabular}

* No significant differences were noticed between the groups, except for height $(P=0.04)$. soya-containing foods for $10 \mathrm{~d}$ before the study and until its completion. This was carefully checked with school restaurants and takeaway restaurants involved in the study. Moreover, the main foods containing polyphenols, such as red fruits, red wine, chocolates, tea or coffee, were prohibited for $3 \mathrm{~d}$ before the beginning of the study, and during the study. Items consumed all through the study are summarised in Table 2 with the main characteristics of the diets.

The study was performed at the Clinical Investigation Center (INSERM and Bordeaux University Hospital, HautLevêque Hospital, Pessac, France) and approved on 28 April 2004 by the regional Medical Ethics Committee (Comité Consultatif pour la Protection des Personnes se prêtant à des Recherches Biomédicales, CCPPRB A, Bordeaux, France). The present study was conducted according to the guidelines laid down in the Declaration of Helsinki, and all procedures involving human subjects/patients were approved by the CCPPRB A, Bordeaux, France. Written informed consent was obtained from all subjects.

Two interventional comparative trials of 10-d soya-based cheese administration were carried out. The first trial was a randomised, two-way cross-over design with an 18-d washout period that assessed the influence of the dietary context, i.e. Western or Asian, on isoflavone pharmacokinetics in Asian subjects (Fig. 1, right side). The second trial assessed the influence of ethnic origin by blindly comparing isoflavone pharmacokinetics in Caucasians and Asians under a Western diet (Fig. 1). These two trials were nested in one design allowing the participation of Asians in both trials at once. Moreover, it allowed the comparison of isoflavone pharmacokinetics in each ethnic group under its usual diet. Caucasians were divided at random into two groups participating in the experiment at two different periods of time to improve their comparability with Asians with regard to the time period of the experimentation. Isoflavone plasma levels and pharmacokinetics were determined blind to the ethnic origin and the nature of the dietary context. Each volunteer received a $56 \mathrm{~g}$ portion of a soya-based cheese daily for $10 \mathrm{~d}$, associated either with a traditional Western or a traditional Asian diet according to the trial. As mentioned earlier, diets previously composed by dieticians were provided either by the school restaurant or by a takeaway restaurant collaborating with the study. Soya-based-cheeses were from Le Sojami ${ }^{\circledR}$ (Agen, France). The soya-based cheese contained 45.97 (SD 1.57) mg of isoflavones in aglycone equivalent, (genistein: 25.45 (SD 0.85) $\mathrm{mg}$; and daidzein: 20.51 (SD 0.80) $\mathrm{mg}$ ). This was checked at the beginning of the trial, at mid-time and at the end. Isoflavones were mainly in the glycosylated form $(>95 \%)$ as assed by a double ELISA assay with or without hydrolysis of the samples (see below for hydrolysis procedure and sample treatments). Meals eaten in the hospital unit were all identical and checked by a dietician. During the 10-d-periods out of the hospital, subjects were provided with pre-prepared meals from the takeaway restaurant or from the school restaurant with recipes approved by dieticians and complying with the specific dietary recommendations based on the age and sex of the subjects and the specific protocol. Table 2 presents the main characteristics of each type of diet.

In both trials, a baseline of $10 \mathrm{ml}$ blood sample was collected before soya food ingestion $\left(T_{0}\right)$. Furthermore, blood samples were collected after 4, 6, 8, 10, 12, 18 and $24 \mathrm{~h}$. 
Table 2. Main characteristics of the Western and Asian diets

\begin{tabular}{lcc}
\hline & Western diet & Asian diet \\
\hline Nutritional characteristics & & $132 \cdot 76-155 \cdot 08$ \\
Proteins $(\mathrm{g} / \mathrm{d})$ & $132 \cdot 76-155 \cdot 08$ & $79 \cdot 02-89 \cdot 62$ \\
Fats $(\mathrm{g} / \mathrm{d})$ & $79 \cdot 02-89 \cdot 62$ & $37 \cdot 26-43 \cdot 05$ \\
Saturated fat $(\mathrm{g} / \mathrm{d})$ & $37 \cdot 26-43 \cdot 05$ & $22 \cdot 81-25 \cdot 72$ \\
Monounsaturated fat $(\mathrm{g} / \mathrm{d})$ & $22 \cdot 81-25 \cdot 72$ & $11 \cdot 55-12 \cdot 56$ \\
Polyunsaturated fat $(\mathrm{g} / \mathrm{d})$ & $11 \cdot 55-12 \cdot 56$ & $334 \cdot 54-470 \cdot 70$ \\
Glucides $(\mathrm{g} / \mathrm{d})$ & $334 \cdot 54-470 \cdot 70$ & $10965-14063$ \\
Energy $(\mathrm{kJ} / \mathrm{d})$ & $10965-14063$ & $25 \cdot 10-30 \cdot 41$ \\
Fibres $(\mathrm{g} / \mathrm{d})$ & $25 \cdot 10-30 \cdot 41$ & $8756-10620$ \\
Minerals $(\mathrm{mg} / \mathrm{d})^{\star}$ & $8756-10620$ & $92-140$ \\
Vitamins $\%$ of the recommendations) $\dagger$ & $92-140$ & \\
Principal items in Western diets by food categories & & Carrots, tomatoes, mushrooms, \\
Cow's milk-based products & Milk, yogurt, butter, cow's milk cheese & green beans, onions, zucchini, \\
Vegetables & Carrots, tomatoes, mushrooms, green beans, & potatoes, leek, cauliflower, capsicums \\
& onions, zucchini, potatoes, leek, cauliflower, & Chicken, pork, beef, eggs \\
Meat & capsicums, green salad & Fish, shrimps, squids \\
Fish & Chicken, pork, beef, turkey, rabbit, eggs & Pasta, noodles, rice, Asian bread \\
Carbohydrates & Fish & Apple, pear, banana, orange and \\
Fruits & Pasta, rice, bread, toasts, maize flakes \\
& Apple, pear, banana, orange and apple or & apple or orange juices \\
Spices & orange juices, apricot or plum jam & Garlic, coriander \\
\hline
\end{tabular}

${ }^{*} \mathrm{Na}, \mathrm{K}, \mathrm{Mg}, \mathrm{P}, \mathrm{Ca}, \mathrm{Fe}$ and $\mathrm{Zn}$.

†Vitamins A, D, E, B $, B_{2}, B_{3}, B_{5}, B_{6}, B_{9}, B_{12}$ and C.

On the 10th day, a plasma kinetic was performed again based on the analysis of samples collected at $0,4,6,8,10,12,18$, 24,48 and $72 \mathrm{~h}$ following the last ingestion of soya-based cheese. Blood samples were collected in Vacutainer ${ }^{\circledR}$ glass tubes (Becton Dickinson, Le Pont-De-Claix, France) containing heparin and lithium as anticoagulants, through an indwelling cannula for samples up to $24 \mathrm{~h}$, and thereafter by venepuncture. Plasma samples were centrifuged at $5000 \mathrm{~g}$ for $5 \mathrm{~min}$ at $4^{\circ} \mathrm{C}$ and stored frozen at $-20^{\circ} \mathrm{C}$ until analysis. Isoflavone concentrations in blood samples were measured by ELISA as previously described ${ }^{(11,24,25)}$. Briefly, before assay, plasmas were first hydrolysed using $\beta$-glucuronidase-arylsulphatase (Roche Diagnostic, Mannheim, Germany) for $24 \mathrm{~h}$ at $37^{\circ} \mathrm{C}$ in acetate buffer $0.05 \mathrm{M}, \mathrm{pH} 5$. After hydrolysis, plasmas were extracted using three times, three volumes of acidified ethyl acetate. Solvent was evaporated to dryness and the extract was resuspended in an assay buffer by sonication. ELISA is a competitive assay using immobilised antigen as the competitor. Specificity tests demonstrated that none of the antibodies recognised equol or $O$-desmethylangolensin, dihydrodaidzein and dihydrogenistein significantly (i.e. $<0.3 \%$ in all cases). In addition, a good parallelism was observed between standard curves and plasma dilution curves ${ }^{(26)}$, showing that no cross-reaction with plasma metabolites could alter genistein or daidzein measurements in plasmas. Any of the conjugates is recognised by any of our antibodies. The method was validated against HPLC ${ }^{(20)}$ and was previously used for isoflavone pharmacokinetic measurements in human subjects ${ }^{(27,28)}$,

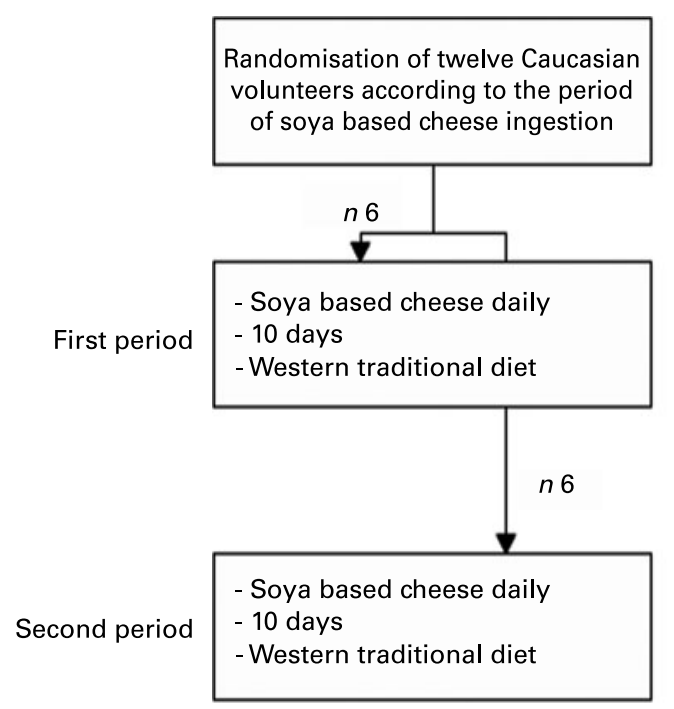

Randomisation of twelve Asian volunteers according to the sequence of dietary context: 'Western then Asian diet' or 'Asian then Western diet'

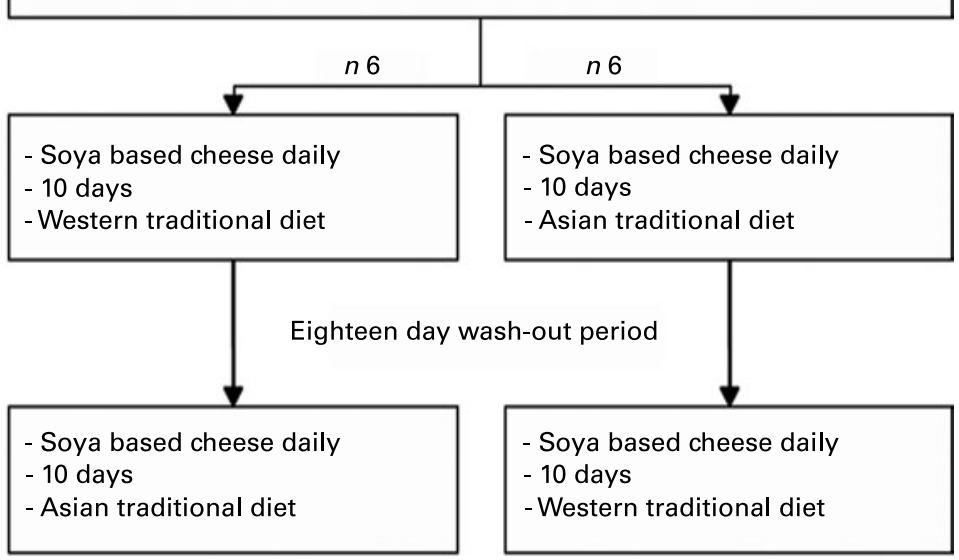

Fig. 1. Experimental design of the study. Asian volunteers were included in a randomised, two-way, cross-over design that assessed the influence of the dietary context. Caucasian volunteers were divided at random into two groups, in order to be compared to Asians under the Western diet at the same periods of time. 
giving results in accordance with previous studies performed using other assay methods.

Pharmacokinetic parameters were obtained using the pharmacokinetic software PK-FIT version 1.2 (RDPP, Montpellier, France). Non-compartmental pharmacokinetic analysis was used to analyse plasma isoflavone concentration-time data. The parameters of maximum concentration $\left(C_{\max }\right)$, and time for maximum concentration $\left(T_{\max }\right)$, were obtained from experimental observations without interpolation. The terminal slope $\left(K_{\mathrm{e}}\right)$ of the concentration-time curve was determined by loglinear regression. Elimination half-life $\left(t_{1 / 2}\right)$ of the terminal log-linear phase was calculated following the equation $0 \cdot 693 / K_{\mathrm{e}}$. The area under the plasma concentration-time curve (AUC) was extrapolated to infinity $\left(\mathrm{AUC}_{\infty}\right)$ or was calculated on a $24 \mathrm{~h}$ basis $\left(\mathrm{AUC}_{24 \mathrm{~h}}\right)$. AUC were determined by trapezoidal and log-trapezoidal methods summing the areas from time 0 to the time of the last time taken into consideration $(t)$ with or without an extrapolation from $t$ to infinity $\left(\mathrm{AUC}_{\infty}\right)$. The extrapolated area was determined by dividing the last detectable concentration by the slope of the terminal log-linear phase. To ensure that comparisons were valid in the parallel controlled studies, $C_{\max }, \mathrm{AUC}_{24 \mathrm{~h}}$ and $\mathrm{AUC}_{\infty}$ values for daidzein and genistein were adjusted to the individual body weight (BW).

In the tables, data are expressed as means and standard deviations. For $\mathrm{AUC}_{24 \mathrm{~h}}$, the number of data is twelve. Comparisons of all parameters were performed on paired Wilcoxon signed-rank tests when comparing day $1-10$, and by Wilcoxon rank-sum tests for other, non-paired comparisons. The effect of the dietary context on the pharmacokinetic parameters of each isoflavone in Asians was studied using a cross-over analysis where intra-subject comparisons were based on paired Wilcoxon signed-rank tests. It followed the strategy proposed by Grizzle ${ }^{(29)}$. Interaction between dietary context and intake period was first studied. If significant at a nominal significance level $0 \cdot 10$ (bilateral analysis), the comparison of dietary contexts should have been only used for the first intake period. Otherwise, comparisons of dietary contexts were to be performed using the two intake periods. Except for interaction analysis in the cross-over strategy, all tests were considered statistically significant at $P<0 \cdot 05$. All analyses were performed with Statistical Analysis Systems Software version 9.2 (SAS Institute, Cary, NC, USA).

\section{Results}

Some data were withdrawn from some analyses because in a few cases, the compliance of the subjects to the protocol was not complete. An Asian volunteer did not present for plasma sampling at day 11 , and a second at day 12 . One Caucasian and four Asians had hidden soya in a sauce during the second kinetic evaluation of one or the other trials, as discovered while analysing dietary records and plasmas. The analyses were still possible since only one, two or three sets of data were lost at the maximum (see figures and tables for number of datasets used). During the hospital phase, the compliance was total and all the data obtained on the first $24 \mathrm{~h}$ could be integrated. In each case, it was considered that the results would be greater impaired if the defecting set of data was kept than if it was removed.
Effect of ethnicity, Asian v. Caucasian, on plasma isoflavone pharmacokinetics under Western diet

Fig. 2 shows the plasma concentrations time course after acute and chronic ingestions in these cases $n$ 12. Table 3 reports $\mathrm{AUC}_{24 \mathrm{~h}}, \mathrm{AUC}_{\infty}, C_{\max }, t_{1 / 2}$ and $T_{\max }$ computed from the individual plasma concentration for both ethnic groups. For $\mathrm{AUC}_{\infty}, T_{\max }$ and $t_{1 / 2}$ values were withdrawn when the dietary protocol was not strictly followed. This is mentioned in the tables' headings.

Acute ingestion. Following the acute ingestion of soyabased cheese in a Western dietary context, the $\mathrm{AUC}_{24 \mathrm{~h}}$ and $C_{\max }$ for both daidzein and genistein were significantly higher in Asians than in Caucasians. For daidzein, AUC were 29.2 (SD 11.2) v. $19.6(\mathrm{SD} 6 \cdot 1) \mathrm{ng} / \mathrm{ml}$ per $\mathrm{h}$ per $\mathrm{kg} \mathrm{BW}$ for Asians and Caucasians, respectively; and $C_{\max }$ were 2.9 (SD 1.1) v. $1.7(\mathrm{SD} 0.5) \mathrm{ng} / \mathrm{ml}$ per $\mathrm{kg} \mathrm{BW}$ for Asians and Caucasians, respectively ( $\mathrm{AUC}_{24 \mathrm{~h}}, P=0.008$ and $C_{\max }, P=0 \cdot 006$ ). For genistein, AUC were 43.7 (SD 15.5) v. 30.1 (SD 9.8) $\mathrm{ng} / \mathrm{ml}$ per h per $\mathrm{kg} \mathrm{BW}$ for Asians and Caucasians, respectively. $C_{\max }$ were 3.7 (SD 1.1) v. $2.4(\mathrm{SD} 0.7) \mathrm{ng} / \mathrm{ml}$ per $\mathrm{kg} \mathrm{BW}$ for Asians and Caucasians, respectively ( $\mathrm{AUC}_{24 \mathrm{~h}}, P=0.032$ and $\left.C_{\max }, P=0.005\right)$. In addition, in both ethnic groups, serum concentrations had not returned to baseline concentrations $24 \mathrm{~h}$ after isoflavone ingestion (Fig. 2).

Chronic ingestions. Daidzein and genistein concentrations in plasma were not nil at $T_{0}$ of day 10 (Fig. 2). They progressively returned to baseline $72 \mathrm{~h}$ after the last intake. At day 10, daidzein $\mathrm{AUC}_{24 \mathrm{~h}}$ and $C_{\max }$ were still significantly higher in Asians $\left(\mathrm{AUC}_{24 \mathrm{~h}}: 32.5\right.$ (SD 11.5) v. 25.6 (SD 5.3) $\mathrm{ng} / \mathrm{ml}$ per $\mathrm{h}$ per $\mathrm{kg}$ $\mathrm{BW}$ for Asians and Caucasians, respectively; $P=0.0032$ ) $\left(C_{\max }: 2.9(\mathrm{SD} 1.1)\right.$ v. $1.7(\mathrm{SD} 0.5) \mathrm{ng} / \mathrm{ml}$ per $\mathrm{kg} \mathrm{BW}$ for Asians and Caucasians, respectively; $P=0 \cdot 03$ ). At day 10 , genistein $C_{\max }$ were the only parameter to be significantly higher in Asians (4.5 (SD 1.6) v. 3.2 (SD 1.2) ng/ml per kg BW for Asians and Caucasians, respectively; $P=0.05)$.

Comparisons between acute and chronic ingestions. A 10-d period of isoflavone intake significantly increased $\mathrm{AUC}_{24} \mathrm{~h}, \mathrm{AUC}_{\infty}$ and $C_{\text {max }}$ of genistein in Caucasian volunteers $(P=0.003,0.01$ and 0.01 , respectively). For daidzein, differences were significant for $\mathrm{AUC}_{24 \mathrm{~h}}$ and $\mathrm{AUC}_{\infty}$ $\left(P=0.04\right.$ and 0.002 , respectively), and $C_{\max }$ were insignificantly different $(P=0.08)$. In Asians, genistein $\mathrm{AUC}_{24 \mathrm{~h}}$, $\mathrm{AUC}_{\infty}$ and $C_{\text {max }}$ were increased $(P=0.004,0.007$ and 0.01 , respectively), but not those of daidzein.

Effect of the dietary context, Asian v. Western diet, on plasma isoflavone pharmacokinetics in Asian volunteers

No significant interaction between period and dietary context was observed, except for the $T_{\max }$ of genistein after chronic ingestions $(P=0 \cdot 06)$.

Pharmacokinetic parameters are summarised in Table 4 and curves are presented in Fig. 3.

Acute ingestion. Daidzein $\mathrm{AUC}_{24 \mathrm{~h}}$ were significantly higher in Asians under an Asian diet (40.8 (SD 15.6) v. 29.2 $(\mathrm{SD} 11.2) \mathrm{ng} / \mathrm{ml}$ per $\mathrm{h}$ per $\mathrm{kg} \mathrm{BW}$ for Asian and Western diets, respectively; $P=0.003$ ), and genistein $\mathrm{AUC}_{24 \mathrm{~h}}$ were significantly lower $(33.3(\mathrm{SD} 10.6) v .43 .7(\mathrm{SD} 15.5) \mathrm{ng} / \mathrm{ml}$ per $\mathrm{h}$ per $\mathrm{kg} \mathrm{BW}$ for Asian and Western diets, respectively; $P=0.02)$. This was sustained by differences in $T_{\max }(P=0.04)$. 

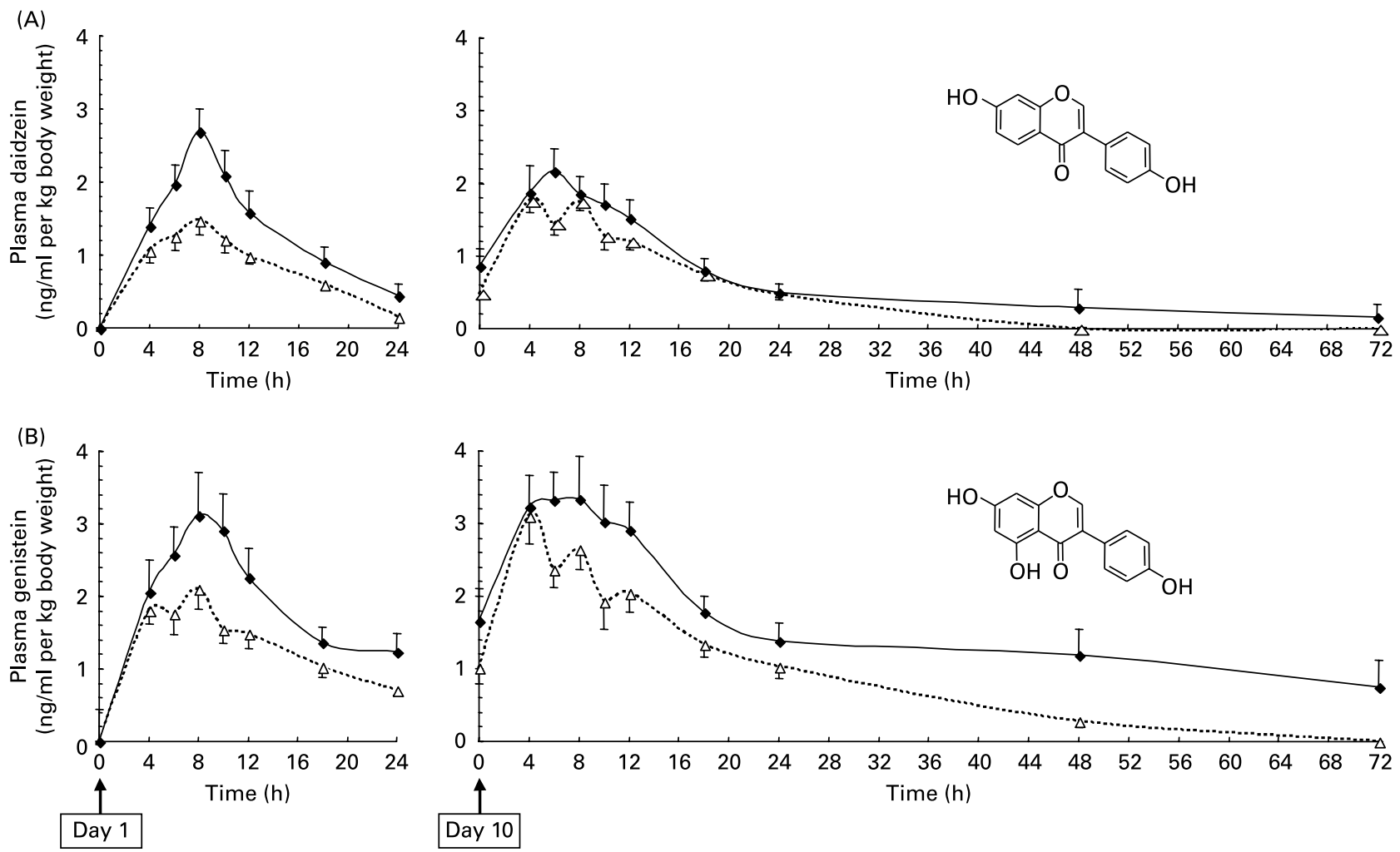

Fig. 2. Pharmacokinetics in Asians and Caucasians on Western diet. Means with their standard errors' plasma concentrations of daidzein (A) and genistein (B) after an acute and a 10-d period of daily ingestion of a soya-based cheese containing 20.51 (SD 0.80) of daidzein and 25.45 (SD 0.85) mg of genistein, associated with traditional Western diets. $n 12$ Caucasian men $(\Delta)$ and $n 12$ Asian men $(\bullet)$

Chronic ingestions. There were no differences between the dietary contexts for any of the parameters considered.

Comparisons between acute and chronic ingestions. Genistein $\mathrm{AUC}_{24 \mathrm{~h}}, \mathrm{AUC}_{\infty}$ and $C_{\max }$ were increased in subjects on a Western $\operatorname{diet}(P=0.005,0.007$ and 0.01 , respectively). This is not the case for daidzein. An increase in $\mathrm{AUC}_{24 \mathrm{~h}}$ and $\mathrm{AUC}_{\infty}$ was also seen for genistein in Asians under an Asian diet ( $P=0.003$ and 0.02 , respectively), but not for $C_{\max }$. For daidzein, the only parameters that were increased under acute ingestion were $\mathrm{AUC}_{\infty} .(P=0.02)$ and $t_{1 / 2}(P=0.03)$.

\section{Comparison between ethnic groups each under its own diet}

Pharmacokinetic parameters are exposed in Table 5 and curves are presented in Fig. 4.

Acute ingestion. Only daidzein $\mathrm{AUC}_{24 \mathrm{~h}}$ were higher in Asians under an Asian diet (40.8 (SD 15.6) v. 19.6 (SD 6.1) ng/ml per $\mathrm{h}$ per $\mathrm{kg} \mathrm{BW}$ for Asians and Caucasians, respectively; $P=0 \cdot 0003)$. No differences were recorded for genistein.

Chronic ingestions. Both $\mathrm{AUC}_{24 \mathrm{~h}}$ and $\mathrm{AUC}_{\infty}$ of daidzein were higher in Asians under an Asian diet than in Caucasians under a Western diet $\left(\mathrm{AUC}_{24 \mathrm{~h}}: 38.5\right.$ (SD 13.3) v. 25.6 (SD 5.3) $\mathrm{ng} / \mathrm{ml}$ per h per $\mathrm{kg} \mathrm{BW}$ for Asians and Caucasians, respectively; $P=0.009$ and $\mathrm{AUC}_{\infty}: 49.9$ (SD 23.8) v. 33.5 (SD 11.1) ng/ml per h per kg BW for Asians and Caucasians, respectively; $P=0.04)$. $C_{\max }$ were not different. For genistein, no differences were recorded.

Comparisons between acute and chronic ingestions. In Caucasians under a Western diet, $\mathrm{AUC}_{24} \mathrm{~h}, \mathrm{AUC}_{\infty}$ and $C_{\max }$ values of genistein all increased significantly $(P=0.003,0.01$ and $0 \cdot 01$, respectively), whereas only $\mathrm{AUC}_{24 \mathrm{~h}}$ and $\mathrm{AUC}_{\infty}$ values increased in Asians under an Asian diet $(P=0.002$ and 0.02 , respectively). $C_{\max }$ were not increased in Asians after chronic intakes. In Caucasians, $\mathrm{AUC}_{24 \mathrm{~h}}$ and $\mathrm{AUC}_{\infty}$ of daidzein were significantly increased $(P=0.04$ and 0.002 , respectively) sustained by an insignificant increase in $C_{\max }$ and $t_{1 / 2}(P=0.08$ for both $)$. This increase was not noticed for Asians under an Asian diet. Only $\mathrm{AUC}_{\infty}$ was increased $(P=0 \cdot 02)$, sustained by a significant increase in $t_{1 / 2}(P=0 \cdot 03)$.

\section{Discussion}

Study design

For the first time, the pharmacokinetics of isoflavones were compared between two ethnic groups in the same periods, in the same study using a homologous assay method. As far as we know, it is the first time that the effect of a dietary context was examined for its ability to modify the pharmacokinetics of isoflavones, and it is the first time that isoflavones pharmacokinetics were compared after acute and chronic ingestions. We included healthy young male subjects in order to avoid the interaction with oestrogens that can occur in women ${ }^{(30,31)}$. The experimentation was carried out over two distinct periods of time separated by a wash-out period of $18 \mathrm{~d}$, using the cross-over design for the assessment of the role of dietary context in Asians. Caucasians were also divided at random into two groups, to be studied during the same periods of time to 
Table 3. Pharmacokinetic parameters for plasma isoflavones after an acute and a 10-d period of daily ingestion of a soya-based cheese, associated with traditional Western diets, in Caucasian men $v$. Asian men

(Mean values and standard deviations)

\begin{tabular}{|c|c|c|c|c|c|c|c|c|c|c|c|c|}
\hline & \multicolumn{5}{|c|}{ Acute ingestion (day 1) } & \multicolumn{5}{|c|}{ Chronic ingestion (day 10) } & & \\
\hline & \multicolumn{2}{|c|}{$\begin{array}{c}\text { Asian } \\
\text { volunteers } \\
(n 12)\end{array}$} & \multicolumn{2}{|c|}{$\begin{array}{c}\text { Caucasian } \\
\text { volunteers } \\
(n 11)\end{array}$} & \multirow[b]{2}{*}{$\begin{array}{l}P \text {-value of ethnic } \\
\text { group effect }\end{array}$} & \multicolumn{2}{|c|}{$\begin{array}{c}\text { Asian } \\
\text { volunteers } \\
(n 11)\end{array}$} & \multicolumn{2}{|c|}{$\begin{array}{c}\text { Caucasian } \\
\text { volunteers } \\
(n 12)\end{array}$} & \multirow[b]{2}{*}{$\begin{array}{l}P \text {-value of ethnic } \\
\text { group effect }\end{array}$} & \multicolumn{2}{|c|}{$\begin{array}{l}P \text {-value of the chronic } \\
\text { ingestion effect }\end{array}$} \\
\hline & Mean & SD & Mean & SD & & Mean & SD & Mean & SD & & Asian origin & Caucasian origin \\
\hline \multicolumn{13}{|l|}{ Daidzein } \\
\hline $\mathrm{AUC}_{24 \mathrm{~h}}(\mathrm{ng} / \mathrm{ml}$ per $\mathrm{h})$ per $\mathrm{kg}$ of body weight & $29 \cdot 2$ & $11 \cdot 2$ & $19 \cdot 6$ & $6 \cdot 1$ & $0.0008^{\star}$ & 32.5 & 11.5 & $25 \cdot 6$ & $5 \cdot 3$ & $0.0032^{*}$ & 0.24 & $0 \cdot 04^{\star}$ \\
\hline $\mathrm{AUC}_{\infty}(\mathrm{ng} / \mathrm{ml}$ per $\mathrm{h})$ per $\mathrm{kg}$ of body weight & $37 \cdot 2$ & $19 \cdot 4$ & $24 \cdot 1$ & $9 \cdot 0$ & 0.09 & $37 \cdot 7$ & $18 \cdot 0$ & 33.5 & $11 \cdot 1$ & 0.83 & 0.32 & $0.002^{*}$ \\
\hline$C_{\max }(\mathrm{ng} / \mathrm{ml})$ per $\mathrm{kg}$ of body weight & $2 \cdot 9$ & $1 \cdot 1$ & 1.7 & 0.5 & $0.006^{*}$ & $2 \cdot 8$ & 0.9 & $2 \cdot 0$ & 0.5 & $0.03^{*}$ & 0.83 & 0.08 \\
\hline$T_{\max }(\mathrm{h})$ & $8 \cdot 8$ & 3.5 & $7 \cdot 8$ & 1.9 & 0.89 & $6 \cdot 4$ & $2 \cdot 1$ & 6.5 & $2 \cdot 7$ & 1.00 & 0.09 & $0 \cdot 14$ \\
\hline$t_{1 / 2}(\mathrm{~h})$ & $8 \cdot 1$ & $6 \cdot 0$ & $7 \cdot 2$ & $2 \cdot 4$ & 0.65 & $7 \cdot 6$ & $2 \cdot 9$ & $10 \cdot 6$ & 4.5 & 0.13 & 0.47 & 0.08 \\
\hline \multicolumn{13}{|l|}{ Genistein } \\
\hline $\mathrm{AUC}_{24 \mathrm{~h}}(\mathrm{ng} / \mathrm{ml}$ per $\mathrm{h})$ per $\mathrm{kg}$ of body weight & $43 \cdot 7$ & $15 \cdot 5$ & $30 \cdot 1$ & 9.8 & $0.032^{*}$ & 63.5 & $25 \cdot 3$ & $43 \cdot 7$ & $17 \cdot 3$ & $0 \cdot 18$ & $0.004^{*}$ & $0.003^{*}$ \\
\hline $\mathrm{AUC}_{\infty}(\mathrm{ng} / \mathrm{ml}$ per $\mathrm{h})$ per $\mathrm{kg}$ of body weight & $55 \cdot 2$ & 23.5 & $42 \cdot 6$ & 16.9 & 0.24 & $83 \cdot 8$ & $39 \cdot 8$ & $64 \cdot 0$ & 30.6 & 0.26 & $0.007^{\star}$ & $0.01^{*}$ \\
\hline$C_{\max }(\mathrm{ng} / \mathrm{ml})$ per $\mathrm{kg}$ of body weight & 3.7 & $1 \cdot 1$ & $2 \cdot 4$ & 0.7 & $0.005^{*}$ & 4.5 & 1.6 & $3 \cdot 2$ & $1 \cdot 2$ & $0.05^{\star}$ & $0.01^{*}$ & $0.01^{*}$ \\
\hline$T_{\max }(\mathrm{h})$ & $8 \cdot 7$ & 3.9 & 6.9 & $2 \cdot 3$ & 0.35 & $6 \cdot 7$ & $2 \cdot 6$ & $5 \cdot 2$ & 1.8 & 0.12 & 0.41 & $0 \cdot 10$ \\
\hline$t_{1 / 2}(\mathrm{~h})$ & $8 \cdot 7$ & 3.5 & $11 \cdot 3$ & $3 \cdot 3$ & 0.07 & $11 \cdot 7$ & $4 \cdot 0$ & $13 \cdot 6$ & $6 \cdot 3$ & 0.69 & 0.32 & 0.97 \\
\hline
\end{tabular}

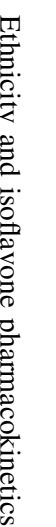

$\mathrm{AUC}_{24 \mathrm{~h}}$, area under the time-concentration curve calculated on a $24 \mathrm{~h}$ basis; $\mathrm{AUC} \mathrm{C}_{\infty}$, AUC extrapolated to infinity; $C_{\max }$, maximum concentration measured in plasma; $T_{\max }$, time at which $C_{\text {max }}$ is measured; $t_{1 / 2}$, half-life period. For all $\mathrm{AUC}_{24}, n 12$.

Comparisons between ethnic groups were based on Wilcoxon rank-sum tests. Comparisons between acute and chronic administrations were based on paired Wilcoxon signed-rank tests.

${ }^{*}$ Differences are significant for $P<0.05$. 
Table 4. Pharmacokinetic parameters for plasma isoflavones in Asian men, after an acute and a 10-d period of daily ingestion of a soya-based cheese, associated with traditional Western diets $v$. traditional Asian diets

(Mean values and standard deviations)

\begin{tabular}{|c|c|c|c|c|c|c|c|c|c|c|c|c|}
\hline & \multicolumn{5}{|c|}{ Acute ingestion (day 1) } & \multicolumn{5}{|c|}{ Chronic ingestion (day 10) } & & \\
\hline & \multicolumn{2}{|c|}{$\begin{array}{l}\text { Asian diet } \\
\quad(n 10)\end{array}$} & \multicolumn{2}{|c|}{$\begin{array}{l}\text { Western } \\
\text { diet }(n 12)\end{array}$} & \multirow[b]{2}{*}{$\begin{array}{c}P \text {-value of dietary } \\
\text { context effect }\end{array}$} & \multicolumn{2}{|c|}{$\begin{array}{c}\text { Asian } \\
\operatorname{diet}(n 9)\end{array}$} & \multicolumn{2}{|c|}{$\begin{array}{l}\text { Western } \\
\text { diet }(n 11)\end{array}$} & \multirow[b]{2}{*}{$\begin{array}{c}P \text {-value of dietary } \\
\text { context effect }\end{array}$} & \multicolumn{2}{|c|}{$\begin{array}{l}P \text {-value of the chronic } \\
\text { ingestion effect }\end{array}$} \\
\hline & Mean & SD & Mean & SD & & Mean & SD & Mean & SD & & Asian diet & Western diet \\
\hline \multicolumn{13}{|l|}{ Daidzein } \\
\hline $\mathrm{AUC}_{24 \mathrm{~h}}(\mathrm{ng} / \mathrm{ml}$ per $\mathrm{h})$ per $\mathrm{kg}$ of body weight & $40 \cdot 8$ & $15 \cdot 6$ & $29 \cdot 2$ & 11.2 & $0.003^{*}$ & 38.5 & 13.3 & 32.5 & $11 \cdot 6$ & 0.06 & 0.63 & 0.24 \\
\hline $\mathrm{AUC}_{\infty}(\mathrm{ng} / \mathrm{ml}$ per $\mathrm{h})$ per $\mathrm{kg}$ of body weight & $36 \cdot 1$ & 14.5 & $39 \cdot 8$ & $20 \cdot 2$ & 0.55 & 43.6 & $15 \cdot 4$ & $39 \cdot 8$ & 20.5 & 0.20 & $0.02^{*}$ & 0.32 \\
\hline$C_{\max }(\mathrm{ng} / \mathrm{ml})$ per $\mathrm{kg}$ of body weight & 2.9 & 1.5 & 3.0 & 1.0 & 0.42 & 3.0 & 1.8 & 2.5 & 0.8 & 1.00 & 0.30 & 0.83 \\
\hline$T_{\max }(\mathrm{h})$ & $8 \cdot 0$ & 1.9 & $8 \cdot 6$ & 3.7 & $0 \cdot 81$ & $7 \cdot 2$ & $2 \cdot 8$ & $6 \cdot 8$ & $2 \cdot 4$ & 0.89 & 0.98 & 0.09 \\
\hline$t_{1 / 2}(\mathrm{~h})$ & $6 \cdot 7$ & 1.6 & $8 \cdot 3$ & 6.4 & 0.84 & $10 \cdot 8$ & 4.7 & $8 \cdot 2$ & $2 \cdot 9$ & 0.34 & $0.03^{*}$ & 0.46 \\
\hline \multicolumn{13}{|l|}{ Genistein } \\
\hline $\mathrm{AUC}_{24 \mathrm{~h}}(\mathrm{ng} / \mathrm{ml}$ per $\mathrm{h})$ per $\mathrm{kg}$ of body weight & $33 \cdot 3$ & $10 \cdot 6$ & 43.7 & $15 \cdot 5$ & $0.02^{*}$ & $49 \cdot 0$ & $18 \cdot 7$ & 63.5 & $25 \cdot 3$ & $0 \cdot 12$ & $0.003^{*}$ & $0.005^{\star}$ \\
\hline $\mathrm{AUC}_{\infty}(\mathrm{ng} / \mathrm{ml}$ per $\mathrm{h})$ per $\mathrm{kg}$ of body weight & $55 \cdot 8$ & $27 \cdot 0$ & $57 \cdot 1$ & $25 \cdot 5$ & 0.84 & 82.7 & 28.4 & $90 \cdot 8$ & 43.9 & 0.89 & $0.02^{*}$ & $0.007^{*}$ \\
\hline$C_{\max }(\mathrm{ng} / \mathrm{ml})$ per $\mathrm{kg}$ of body weight & $3 \cdot 8$ & 2.4 & 3.6 & $1 \cdot 2$ & 0.84 & $4 \cdot 2$ & 1.8 & 4.5 & 1.9 & 0.49 & 0.30 & $0.01^{*}$ \\
\hline$T_{\max }(\mathrm{h})$ & $6 \cdot 6$ & $2 \cdot 1$ & $8 \cdot 2$ & $4 \cdot 1$ & $0.04^{*}$ & $5 \cdot 2$ & 3.4 & 7.5 & 2.5 & 0.86 & 0.81 & \\
\hline$t_{1 / 2}(\mathrm{~h})$ & $11 \cdot 3$ & 4.4 & 9.6 & $3 \cdot 1$ & 0.42 & $14 \cdot 2$ & 8.5 & $12 \cdot 5$ & $4 \cdot 3$ & 0.89 & 0.58 & \\
\hline
\end{tabular}

$\mathrm{AUC}_{24 \mathrm{~h}}$, area under the time-concentration curve calculated on a $24 \mathrm{~h}$ basis; $\mathrm{AUC} \mathrm{C}_{\infty}, \mathrm{AUC}$ extrapolated to infinity; $C_{\text {max }}$, maximum concentration measured in plasma; $T_{\text {max }}$, time at which $C_{\text {max }}$ is measured; $t_{1 / 2}$, half-life period. For all $\mathrm{AUC}_{24 \mathrm{~h}}, n 12$.

Statistical analysis was performed according to a cross-over analysis strategy (see text), except for $\mathrm{AUC}_{24 \mathrm{~h}}$ comparisons. All intra-subject comparisons were based on paired Wilcoxon signed-rank tests. Differences are significant for $P<0.05$. 

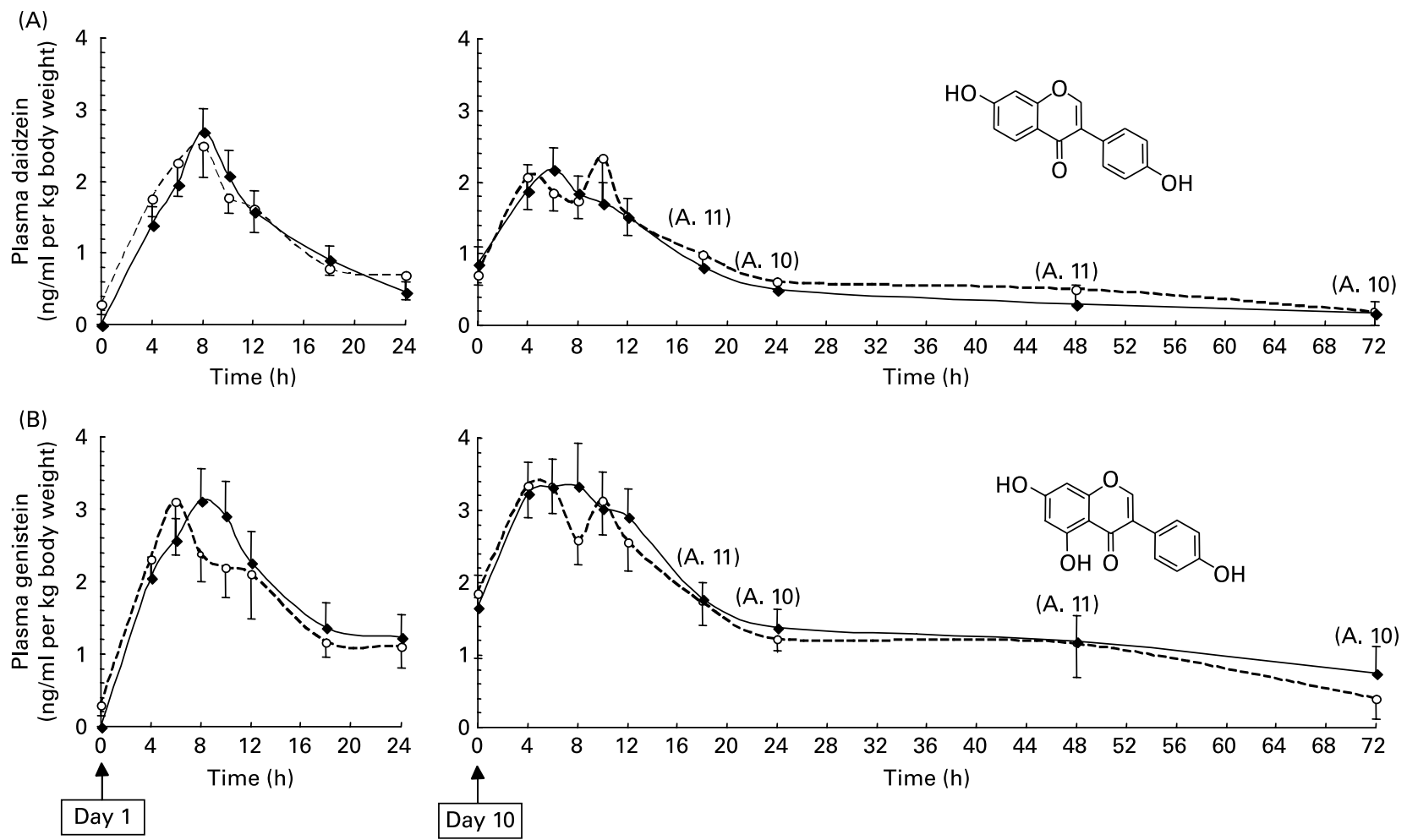

Fig. 3. Pharmacokinetics in Asians under Asian or Western dietary context. Means with their standard errors' plasma concentrations of daidzein (A) and genistein (B) after an acute and a 10-d period of daily ingestion of a soya-based cheese containing 20.51 (SD 0.80) of daidzein and 25.45 (SD 0.85 ) mg of genistein. $n 12$ Asian men who consumed a traditional Western diet $(\diamond)$ or a traditional Asian diet $(O)$ in a cross-over trial, except when a number is apposed into brackets.

improve the comparability with their Asian counterparts (Fig. 1). For practical reasons, the wash-out period was fixed at $18 \mathrm{~d}$ since at least seven $t_{1 / 2}$ are required. Recent data have mentioned $t_{1 / 2}$ durations over $25 \mathrm{~h}^{(27,28,32)}$. We chose to chronically expose volunteers for a 10-d duration since 10-d adaptation phenomena had already been registered for carbohydrates ${ }^{(33)}$. There were great differences in the individual weight of volunteers, so the pharmacokinetic parameters were adjusted to this parameter to reduce its impact on the inter-individual variations. Daidzein concentrations in plasma were lower than those of genistein due to respective concentrations of both compounds in soya-based cheese and to a shorter plasma residence time for daidzein ${ }^{(27,28,34,35)}$. $\mathrm{AUC}_{24 \mathrm{~h}}$ were always lower than $\mathrm{AUC}_{\infty}$. This meant that at $24 \mathrm{~h}$, the elimination process was far from over. In some cases, differences were seen on $\mathrm{AUC}_{24 \mathrm{~h}}$ and were not on $\mathrm{AUC}_{\infty}$; this can be explained because some volunteers exhibited recirculation phenomena after $24 \mathrm{~h}$. Indeed, it was shown by other authors that, after passing the gut wall, isoflavones are sent to the liver for the first step of conjugation. A portion of the compounds are metabolised as bile compounds and return to the gut. Once in the gut, they can re-enter the bloodstream via the enterocyte uptake. These phenomena increased the residence time in the blood and therefore the area under the curve. This recirculation did not appear in all volunteers. As a consequence, this raised the standard deviation about the mean values of $\mathrm{AUC}_{\infty}$ leading to a decrease in significance. None of the volunteers presented an equol production as tested using the specific ELISA previously set up ${ }^{(11,20,25)}$. This reduced the inter-individual variability of pharmacokinetic parameters. Indeed, as shown in a previous paper, equol production modifies the bioavailability of daidzein ${ }^{(27,28)}$.

Effect of ethnicity, Asian v. Caucasian, on plasma isoflavone pharmacokinetics under Western diet

The values of pharmacokinetic parameters fitted with previous data from other authors ${ }^{(3,27,28,34)}$ validating the relevancy of the assay methods.

Acute ingestion. The higher values of $\mathrm{AUC}_{24 \mathrm{~h}}$ and $C_{\max }$ obtained in Asians indicate that Asians better absorb isoflavones than Caucasians on acute ingestion of isoflavones included in a soya-based cheese. The absorption efficiency may be different between ethnic groups since the $T_{\max }$ and $t_{1 / 2}$ two parameters influenced by the speed of absorption and elimination processes were similar.

Chronic ingestions. After $10 \mathrm{~d}$ of chronic ingestions, differences were reduced for daidzein since the AUC and $C_{\max }$ increased more in Caucasians than in Asians. For genistein, it was the same and only $C_{\max }$ remained higher in Asians.

Comparisons between acute and chronic ingestions. The absence of increases in the combination of $\mathrm{AUC}_{24 \mathrm{~h}}, \mathrm{AUC}_{\infty}$ and $C_{\max }$ of daidzein in Asians was unexpected. Indeed, because $t_{1 / 2}$ varies from 6 to $24 \mathrm{~h}$ for daidzein and genistein ${ }^{(27,28,32)}$, it was expected to find isoflavones in plasmas collected at $T_{0}$ of day 10 and to observe an increase in $\mathrm{AUC}_{24} \mathrm{~h}, \mathrm{AUC}_{\infty}$ and $C_{\max }$ values. This was true for genistein and for daidzein in Caucasians, but not for daidzein in Asians (Table 3). This may indicate a modification of the daidzein enzymatic pathways involved in pharmacokinetic phenomena in these specific 
Table 5. Pharmacokinetic parameters for plasma isoflavones after an acute and a 10-d period of daily ingestion of a soya-based cheese, associated with traditional Western diets in Caucasian men $v$. traditional Asian diets in Asian men

(Mean values and standard deviations)

\begin{tabular}{|c|c|c|c|c|c|c|c|c|c|c|c|c|}
\hline & \multicolumn{5}{|c|}{ Acute ingestion (day 1 ) } & \multicolumn{5}{|c|}{ Chronic ingestion (day 10) } & & \\
\hline & \multicolumn{2}{|c|}{$\begin{array}{l}\text { Asian } \\
\text { volunteers } \\
(n 12)\end{array}$} & \multicolumn{2}{|c|}{$\begin{array}{l}\text { Caucasian } \\
\text { volunteers } \\
\quad(n 11)\end{array}$} & \multirow[b]{2}{*}{$\begin{array}{l}P \text {-value of ethnic } \\
\text { group and/or dietary } \\
\text { context effect }\end{array}$} & \multicolumn{2}{|c|}{$\begin{array}{l}\text { Asian } \\
\text { volunteers } \\
(n 9)\end{array}$} & \multicolumn{2}{|c|}{$\begin{array}{l}\text { Caucasian } \\
\text { volunteers } \\
\quad(n 12)\end{array}$} & \multirow[b]{2}{*}{$\begin{array}{l}P \text {-value of ethnic } \\
\text { group and/or dietary } \\
\text { context effect }\end{array}$} & \multicolumn{2}{|c|}{$\begin{array}{l}P \text {-value of the chronic } \\
\text { ingestion effect }\end{array}$} \\
\hline & Mean & SD & Mean & SD & & Mean & SD & Mean & SD & & Asian origin & $\begin{array}{c}\text { Caucasian } \\
\text { origin }\end{array}$ \\
\hline \multicolumn{13}{|l|}{ Daidzein } \\
\hline $\mathrm{AUC}_{24 \mathrm{~h}}(\mathrm{ng} / \mathrm{ml}$ per $\mathrm{h})$ per $\mathrm{kg}$ of body weight & $40 \cdot 8$ & $15 \cdot 6$ & $19 \cdot 6$ & $6 \cdot 1$ & $0.0003^{*}$ & 38.5 & $13 \cdot 3$ & $25 \cdot 6$ & $5 \cdot 3$ & $0.009^{*}$ & 0.63 & $0.04^{\star}$ \\
\hline $\mathrm{AUC}_{\infty}(\mathrm{ng} / \mathrm{ml}$ per $\mathrm{h})$ per $\mathrm{kg}$ of body weight & $36 \cdot 1$ & 14.5 & $24 \cdot 1$ & $9 \cdot 0$ & 0.06 & 49.9 & 23.8 & 33.5 & 11.1 & $0.04^{*}$ & $0.02^{*}$ & $0.002^{*}$ \\
\hline$C_{\max }(\mathrm{ng} / \mathrm{ml})$ per $\mathrm{kg}$ of body weight & 2.9 & 1.5 & 1.7 & 0.5 & 0.06 & $3 \cdot 2$ & 1.8 & $2 \cdot 0$ & 0.5 & 0.22 & 0.30 & 0.08 \\
\hline$T_{\max }(\mathrm{h})$ & $8 \cdot 0$ & 1.9 & $7 \cdot 8$ & 1.9 & 0.88 & $7 \cdot 8$ & 3.1 & 6.5 & $2 \cdot 7$ & 0.51 & 0.98 & 0.14 \\
\hline$t_{1 / 2}(\mathrm{~h})$ & $6 \cdot 7$ & 1.6 & $7 \cdot 2$ & $2 \cdot 4$ & 0.97 & $10 \cdot 6$ & 4.4 & $10 \cdot 6$ & 4.5 & 0.86 & $0.03^{*}$ & 0.08 \\
\hline \multicolumn{13}{|l|}{ Genistein } \\
\hline $\mathrm{AUC}_{24 \mathrm{~h}}(\mathrm{ng} / \mathrm{ml}$ per $\mathrm{h})$ per $\mathrm{kg}$ of body weight & 33.3 & $10 \cdot 6$ & $30 \cdot 1$ & 9.8 & 0.41 & $49 \cdot 0$ & $18 \cdot 7$ & 43.7 & $17 \cdot 3$ & 0.60 & $0.002^{*}$ & $0.003^{*}$ \\
\hline $\mathrm{AUC}_{\infty}(\mathrm{ng} / \mathrm{ml}$ per $\mathrm{h})$ per kg of body weight & $55 \cdot 8$ & $27 \cdot 0$ & $42 \cdot 6$ & $16 \cdot 9$ & 0.20 & $97 \cdot 3$ & $51 \cdot 1$ & $64 \cdot 0$ & 30.6 & $0 \cdot 10$ & $0.02^{*}$ & $0.01^{*}$ \\
\hline$C_{\max }(\mathrm{ng} / \mathrm{ml})$ per $\mathrm{kg}$ of body weight & 3.8 & $2 \cdot 4$ & $2 \cdot 4$ & 0.7 & 0.43 & 4.6 & $2 \cdot 1$ & $3 \cdot 2$ & $1 \cdot 2$ & $0 \cdot 13$ & 0.30 & $0.01^{*}$ \\
\hline$T_{\max }(\mathrm{h})$ & $6 \cdot 6$ & $2 \cdot 1$ & 6.9 & $2 \cdot 3$ & 0.44 & $6 \cdot 0$ & 3.9 & $5 \cdot 2$ & 1.8 & 0.87 & 0.81 & 0.10 \\
\hline$t_{1 / 2}(\mathrm{~h})$ & $11 \cdot 3$ & 4.4 & $11 \cdot 3$ & 3.3 & 0.97 & $14 \cdot 3$ & 7.9 & $13 \cdot 6$ & $6 \cdot 3$ & 0.97 & 0.58 & 0.97 \\
\hline
\end{tabular}

$\mathrm{AUC}_{24 \mathrm{~h}}$, area under the time-concentration curve calculated on a $24 \mathrm{~h}$ basis; $\mathrm{AUC} \mathrm{C}_{\infty}$, AUC extrapolated to infinity; $C_{\max }$, maximum concentration measured in plasma; $T_{\max }$, time at which $C_{\max }$ is measured; $t_{1 / 2}$, half-life period. For all $\mathrm{AUC}_{24 \mathrm{~h}}, n 12$.

Comparisons between groups were based on Wilcoxon rank-sum tests. Comparisons between acute and chronic administrations were based on Wilcoxon signed-rank tests.

* Differences are significant for $P<0.05$. 

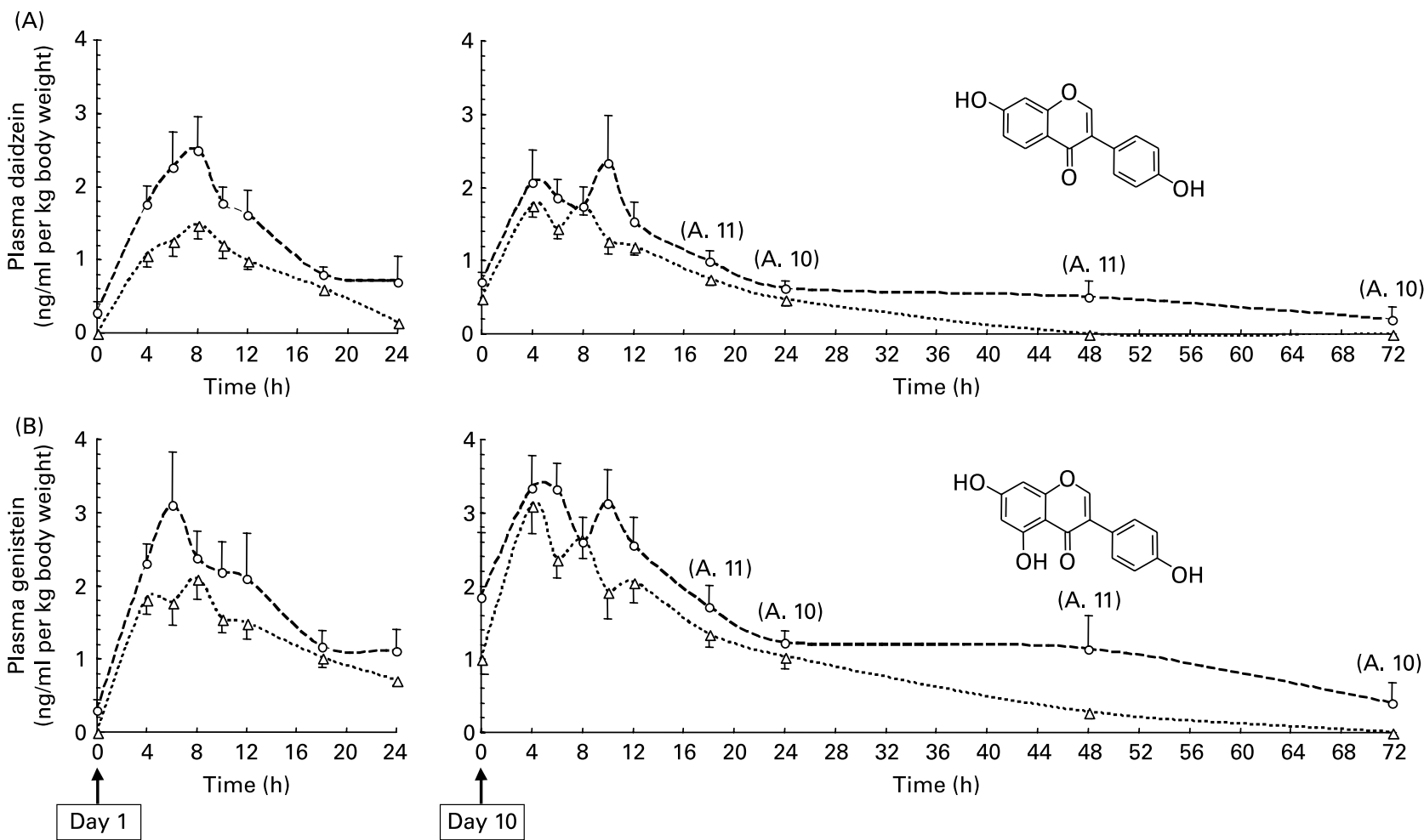

Fig. 4. Pharmacokinetics in Asians and Caucasians each under their own dietary context. Means with their standard errors' plasma concentrations of daidzein (A) and genistein (B) after an acute and a 10-d period of daily ingestion of a soya-based cheese containing 20.51 (SD 0.80 ) of daidzein and 25.45 (SD 0.85 ) mg of genistein. $n 12$ Caucasian men consuming their Western diets $(\Delta)$ and $n 12$ Asian men consuming their traditional Asian diets $(O)$, except when a number is apposed into brackets.

conditions. This observation was linked to a diminution of $T_{\max }$, suggesting a shorter absorption process. This is possibly due to an interaction of the Western food with the gut wall and flora. In Asian and Caucasian women, it was shown that gut transit time depending on diet can influence urine isoflavone excretion $^{(36)}$. Daidzein is the only compound to be influenced after a 10-d period of chronic ingestion, probably as a result of its shorter residence time in plasma.

\section{Effect of dietary contexts in Asians}

Acute ingestion. No statistical differences appeared when parameters were compared for daidzein or genistein in one or the other dietary contexts, except when AUC were calculated on a $24 \mathrm{~h}$ basis. However, in that case, the superiorities were inverted for the two isoflavones, values being higher in Asians under an Asian diet for daidzein and higher in Asians under a Western diet for genistein (Table 4). Therefore, no significant impact of the dietary context on isoflavone bioavailability can be concluded from these data.

Chronic ingestions. Comparing the dietary context and after chronic ingestions, there were no longer differences in any of the parameters analysed, whatever the isoflavone considered. This leads to the conclusion that the pharmacokinetics of both daidzein and genistein delivered in soya-based cheese are not influenced by the dietary context in Asians.

Comparisons between acute and chronic ingestions. The expected increases in $\mathrm{AUC}$ and $C_{\max }$ linked to long $t_{1 / 2}$ of the two isoflavones were only noticed for genistein.
For daidzein, whatever the dietary context there were no consistent increases in AUC and $C_{\max }$. This would suggest that a metabolic adaptation could occur in Asians after chronic ingestion of daidzein affecting the efficiency of daidzein absorption. Because $t_{1 / 2}$ were not affected, it can be hypothesised that this adaptation affects the absorption process and may take place at the gut level. It may be linked to a slight modification of the gut flora composition linked to the nature of the food item ingested.

\section{Comparisons of ethnic groups under their own traditional diet}

Classically, when Asians are compared to Westerners, this comparison includes both ethnic and dietary characteristics. Therefore, we compared the pharmacokinetics of each ethnic group on its own habitual diet. In these conditions, daidzein AUC were consistently higher in Asians than in Caucasians when each was on their traditional food and whatever the exposure duration: acute intake or ten chronic intakes. This finding was sustained by previous data ${ }^{(36)}$ obtained in Asian and Caucasian women challenged with higher doses of isoflavones. It was also observed that $\mathrm{AUC}_{24 \mathrm{~h}}, \mathrm{AUC}_{\infty}$ and $C_{\text {max }}$ for genistein and daidzein consistently increased in Caucasians after chronic ingestion, whereas it was not the case for daidzein and for genistein $C_{\max }$ in Asians. This would suggest that under ten chronic ingestions, in these specific conditions (doses, rhythm of ingestion and food intake), Caucasians were able to experience an increase in AUC and $C_{\max }$, but not Asians. 
Because $t_{1 / 2}$ were never modified whatever the ethnic group or the dietary context, it could be suggested that the differences reported here may be linked to differences at the gut level. Indeed, when genetic differences between groups were observed in previous studies for other compounds, it was shown that $t_{1 / 2}$ were different ${ }^{(15,18)}$. This indicates that, here, the endogenous enzymes involved in absorption, cell storage and elimination and which influence $t_{1 / 2}$ of isoflavones were probably not very different between Asians and Caucasians. At any rate, the inter-individual differences may have masked the inter-ethnic differences. If enzymes were not fundamentally different between the two ethnic groups, the difference in absorption could possibly be due to differences either in the background diet or in gut flora activity ${ }^{(37)}$. Indeed, gut flora is known to be influenced by the dietary context ${ }^{(3)}$ and to influence isoflavone bioavailability ${ }^{(36,37)}$. Moreover, a microflora difference between Asians and Caucasians was already hypothesised previously ${ }^{(36)}$, although never demonstrated as far as we know.

The present study also showed that Caucasians experienced a greater increase in $\mathrm{AUC}_{24 \mathrm{~h}}, \mathrm{AUC}_{\infty}$ and $C_{\max }$ of daidzein than Asians after ten chronic ingestions when each ethnic group was on its own traditional diet. If this phenomenon is maintained on longer exposure, it may lead to an accumulation in Caucasians and not in Asians. Therefore, on chronic daily exposure, Asians would have lower isoflavone plasma levels than Caucasians and this for a similar intake. This was already suggested by Gooderham \& Adlercreutz ${ }^{(13)}$ comparing their results to those obtained by Adlercreutz ${ }^{(14)}$. In both studies, the assay method and the isoflavone delivery were similar and the plasma levels were 371 (SD 93) and $107 \mathrm{ng} / \mathrm{ml}$ for Caucasians and Asians, respectively. Looking at the scattered literature produced either on Asians or on Caucasians, the effect observed in the present study seems to be confirmed. Indeed, several studies produced on Asians ${ }^{(38-41)}$ found isoflavone plasma levels of 185, 159 (SD 80), 219 (SD 330) and $148 \mathrm{ng} / \mathrm{ml}$, respectively. In all these studies, volunteers were on traditional Asian diet (from 39 to $46.4 \mathrm{mg}$ isoflavones/d). They were followed without fasting, and the blood sampling was performed in the morning between 10 and $12 \mathrm{~h}$ postingestion. At the same time in studies dealing with long-term exposure of Caucasians to isoflavones ${ }^{(11,13,42)}$, the isoflavones plasma levels were 371 (SD 93), 177 (SD 104) and 941 (SD 370) ng/ml for a daily intake of 45,10 and $100 \mathrm{mg}$ of isoflavone, respectively. This time again the delay between isoflavone intake and plasma collection was between 10 and $12 \mathrm{~h}$.

\section{Conclusion}

The present manuscript provides evidence that on acute intake, Asians absorb isoflavones from soya cheese better than Caucasians, regardless of whether the background diet is Western or Asian. In Asians, the pharmacokinetics of isoflavones from soya-based cheese were not influenced by dietary context. Finally, chronic ingestions lead to a consistent increase in the AUC and $C_{\max }$ of isoflavones in Caucasians under a Western diet, but this was not true for daidzein in Asians whatever the background diet, Asian or Western. This could have consequences on isoflavone bioavailability after chronic ingestions. A greater understanding of isoflavone pharmacokinetics could strengthen some hypothesis so far on a variety of potential health outcomes.

\section{Acknowledgements}

The present study was supported by the Research Ministry of France, RARE Program No. 03P221 and by the Région Aquitaine through Isle Royale Natural History Association funding. S. V. is the recipient of a fellowship (CIFRE No. 856/2003) from Arkopharma Pharmaceutical Laboratories and the National Association of Technical Research, Research Ministry of France. There is no conflict of interest regarding the present work. The authors thank the volunteers, Danièle Lamazière, the dietician, Marcelle Pontgahet and Claude Maïs, the nurses, Dr Virginie Bernard for inclusion visits and Dr Demotes-Mainard the CIC director. We acknowledge Dr Jean-James Garreau for the soya-based cheeses and Russell Wallace and Dr Mylene Potier for their kind help with the English. C. B.-P. applied to the Regional Applied Research Efforts funding program. C. B.-P., N. M. and P. P. conceived and designed the study, M. D. was responsible for organising and incorporating volunteers and collecting blood samples, S. V. and V. L. were responsible for assaying isoflavones in blood samples, N. M. was responsible for conducting the pharmacokinetic analysis; P. P. and J. A. were responsible for conducting the statistical analysis; S. V., P. C. and C. B.-P. for analysing the results; S. V., M. D., P. S. and C. B.-P. for co-ordinating the scientific and technical part of the study; and S. V. and C. B-.P for writing the manuscript. All authors provided input to the manuscript, and none of the authors had any conflict of financial or personal interest.

\section{References}

1. Cassidy A, Brown JE, Hawdon A, et al. (2006) Factors affecting the bioavailability of soy isoflavones in humans after ingestion of physiologically relevant levels from different soy foods. $J$ Nutr 136, 45-51.

2. Nielsen IL \& Williamson G (2007) Review of the factors affecting bioavailability of soy isoflavones in humans. Nutr Cancer 57, $1-10$.

3. Rowland I, Faughnan M, Hoey L, et al. (2003) Bioavailability of phyto-oestrogens. Br J Nutr 89, Suppl. 1, S45-S58.

4. Arai Y, Watanabe S, Kimira M, et al. (2000) Dietary intakes of flavonols, flavones and isoflavones by Japanese women and the inverse correlation between quercetin intake and plasma LDL cholesterol concentration. J Nutr 130, 2243-2250.

5. Kimira M, Arai Y, Shimoi K, et al. (1998) Japanese intake of flavonoids and isoflavonoids from foods. $J$ Epidemiol 8, 168-175.

6. Nagata C, Shimizu H, Takami R, et al. (2002) Soy product intake and serum isoflavonoid and estradiol concentrations in relation to bone mineral density in postmenopausal Japanese women. Osteoporos Int 13, 200-204.

7. Liu Z, Li W, Sun J, et al. (2004) Intake of soy foods and soy isoflavones by rural adult women in China. Asia Pac J Clin Nutr 13, 204-209.

8. Mei J, Yeung SS \& Kung AW (2001) High dietary phytoestrogen intake is associated with higher bone mineral density in postmenopausal but not premenopausal women. $J$ Clin Endocrinol Metab 86, 5217-5221.

9. Surh J, Kim MJ, Koh E, et al. (2006) Estimated intakes of isoflavones and coumestrol in Korean population. Int J Food Sci Nutr 57, 325-344.

10. Keinan-Boker L, Peeters PH, Mulligan AA, et al. (2002) Soy product consumption in 10 European countries: the European Prospective Investigation into Cancer and Nutrition (EPIC) Study. Public Health Nutr 5, 1217-1226. 
11. Bennetau-Pelissero C, Arnal-Schnebelen B, Lamothe V, et al. (2003) ELISA as a new method to measure genistein and daidzein in food and human fluids. Food Chem 82, 645-658.

12. Rannikko A, Petas A, Rannikko S, et al. (2006) Plasma and prostate phytoestrogen concentrations in prostate cancer patients after oral phytoestogen supplementation. Prostate 66, 82-87.

13. Gooderham MH, Adlercreutz H, Ojala ST, et al. (1996) A soy protein isolate rich in genistein and daidzein and its effects on plasma isoflavone concentrations, platelet aggregation, blood lipids and fatty acid composition of plasma phospholipid in normal men. J Nutr 126, 2000-2006.

14. Adlercreutz H, Markkanen H \& Watanabe S (1993) Plasma concentrations of phyto-oestrogens in Japanese men. Lancet 342, $1209-1210$.

15. Klotz U (2007) The role of pharmacogenetics in the metabolism of antiepileptic drugs: pharmacokinetic and therapeutic implications. Clin Pharmacokinet 46, 271-279.

16. Alam AN, Saha JR, Dobkin JF, et al. (1988) Interethnic variation in the metabolic inactivation of digoxin by the gut flora. Gastroenterology 95, 117-123.

17. Messina M, Nagata C \& Wu AH (2006) Estimated Asian adult soy protein and isoflavone intakes. Nutr Cancer 55, 1-12.

18. Chen ML (2006) Ethnic or racial differences revisited: impact of dosage regimen and dosage form on pharmacokinetics and pharmacodynamics. Clin Pharmacokinet 45, 957-964.

19. Lu LJ, Grady JJ, Marshall MV, et al. (1995) Altered time course of urinary daidzein and genistein excretion during chronic soya diet in healthy male subjects. Nutr Cancer 24, 311-323.

20. Mathey J, Lamothe V, Coxam V, et al. (2006) Concentrations of isoflavones in plasma and urine of post-menopausal women chronically ingesting high quantities of soy isoflavones. $J$ Pharm Biomed Anal 41, 957-965.

21. Setchell KD, Faughnan MS, Avades T, et al. (2003) Comparing the pharmacokinetics of daidzein and genistein with the use of ${ }^{13}$ C-labeled tracers in premenopausal women. Am J Clin Nutr 77, 411-419.

22. Wiseman H, Casey K, Bowey EA, et al. (2004) Influence of $10 \mathrm{wk}$ of soy consumption on plasma concentrations and excretion of isoflavonoids and on gut microflora metabolism in healthy adults. Am J Clin Nutr 80, 692-699.

23. Adlercreutz H, Honjo H, Higashi A, et al. (1991) Urinary excretion of lignans and isoflavonoid phytoestrogens in Japanese men and women consuming a traditional Japanese diet. Am J Clin Nutr 54, 1093-1100.

24. Bennetau-Pelissero C, Le Houerou C, Lamothe V, et al. (2000) Synthesis of haptens and conjugates for ELISAs of phytoestrogens. Development of the immunological tests. J Agric Food Chem 48, 305-311.

25. Le Houerou C, Bennetau-Pelissero C, Lamothe V, et al. (2000) Syntheses of novel hapten-protein conjugates for production of highly specific antibodies to formononetin, daidzein and genistein. Tetrahedron 56, 295-301.

26. Bennetau-Pelissero C, Le Houerou C, Le Menn F, et al. (1998) ELISAs for genistein and daidzein. Cost 916 Bioactive Plant Cell Wall Components in Nutrition and Health. Phytoestrogens: Exposure, Bioavailability, Health Benefits and Safety Concerns, Doorweth, The Netherlands, April 17-18, pp. 55-62 [S Bausch-Goldbohm, A Kardinaal and F Serra, editors]. Luxembourg: European Communities.
27. Vergne S, Bennetau-Pelissero C, Lamothe V, et al. (2008) Higher bioavailability of isoflavones after a single ingestion of a soya-based supplement than a soya-based food in young healthy males. Br J Nutr 99, 333-344.

28. Vergne S, Titier K, Bernard V, et al. (2007) Bioavailability and urinary excretion of isoflavones in humans: effects of soy-based supplements formulation and equol production. J Pharm Biomed Anal 43, 1488-1494.

29. Grizzle JE (1965) The two-period change-over design an its use in clinical trials. Biometrics 21, 467-480.

30. Nagel SC, vom Saal FS \& Welshons WV (1998) The effective free fraction of estradiol and xenoestrogens in human serum measured by whole cell uptake assays: physiology of delivery modifies estrogenic activity. Proc Soc Exp Biol Med 217, 300-309.

31. Pfeiffer E, Treiling CR, Hoehle SI, et al. (2005) Isoflavones modulate the glucuronidation of estradiol in human liver microsomes. Carcinogenesis 26, 2172-2178.

32. Richelle M, Pridmore-Merten S, et al. (2002) Hydrolysis of isoflavone glycosides to aglycones by beta-glycosidase does not alter plasma and urine isoflavone pharmacokinetics in postmenopausal women. J Nutr 132, 2587-2592.

33. Albert JD, Legaspi A, Horowitz GD, et al. (1986) Peripheral tissue metabolism in man with varied disease states and similar weight loss. J Surg Res 40, 374-381.

34. Setchell KD, Brown NM, Desai P, et al. (2001) Bioavailability of pure isoflavones in healthy humans and analysis of commercial soy isoflavone supplements. J Nutr 131, 1362S-1375S.

35. Watanabe S, Yamaguchi M, Sobue T, et al. (1998) Pharmacokinetics of soybean isoflavones in plasma, urine and feces of men after ingestion of $60 \mathrm{~g}$ baked soybean powder (kinako). J Nutr 128, 1710-1715.

36. Zheng Y, Hu J, Murphy PA, et al. (2003) Rapid gut transit time and slow fecal isoflavone disappearance phenotype are associated with greater genistein bioavailability in women. $J$ Nutr 133, 3110-3116.

37. Atkinson C, Frankenfeld CL \& Lampe JW (2005) Gut bacterial metabolism of the soy isoflavone daidzein: exploring the relevance to human health. Exp Biol Med (Maywood) 230, $155-170$.

38. Uehar M, Arai Y, Watanabe S, et al. (2000) Comparison of plasma and urinary phytoestrogens in Japanese and Finnish women by time-resolved fluoroimmunoassay. Biofactors 12, 217-225.

39. Yamamoto S, Sobue T, Sasaki S, et al. (2001) Validity and reproducibility of a self-administered food-frequency questionnaire to assess isoflavone intake in a Japanese population in comparison with dietary records and blood and urine isoflavones. J Nutr 131, 2741-2747.

40. Morton MS, Arisaka O, Miyake N, et al. (2002) Phytoestrogen concentrations in serum from Japanese men and women over forty years of age. J Nutr 132, 3168-3171.

41. Ozasa K, Nakao M, Watanabe Y, et al. (2005) Association of serum phytoestrogen concentration and dietary habits in a sample set of the JACC Study. J Epidemiol 15, Suppl. 2, S196-S202.

42. Vedrine N, Mathey J, Morand C, et al. (2006) One-month exposure to soy isoflavones did not induce the ability to produce equol in postmenopausal women. Eur J Clin Nutr 60, 1039-1045. 